\title{
Circular Economy as an Answer to the Challenge of Improving the Quality of Life
}

\author{
Elżbieta SZCZYGIEŁ
}

Pedagogical University of Krakow, Kraków, Poland; elzbieta.szczygiel@upkrakow.pl

\begin{abstract}
The paper is an attempt to presents the influence the idea of circular economy on improving the quality of life. In the article the author presents the quality of life concept (understands as the element of sustainable development), as well as living standard idea, and the key assumption of circular economy: i.a. the 'take-make-waste' approach, characteristic of the linear model of economy, as well as 'reduce, reuse, recycle and recover' which is used in circular economy. It seems that circular economy could have positive effect on increasing the quality of life, especially due to the fact that environment aspects have it. The main part of the article is the literature review in the field of quality of life and circular economy connection. As an attempt to demonstrate of dependence between analysed phenomenon, author uses the available data come from international databases (Human Development Index and Quality of Life index, as well as from Eurostat). The preliminary analysis of existing relation is based on linear regression model, which results state that there is a positive influence of circular economy on increasing quality of life.
\end{abstract}

Keywords: circular economy; linear model of economy; quality of life; living standard; sustainable development; statistical analysis

JEL Classification: C0; O1; Q5

\section{Introduction}

The present paper is the second one in the publication series devoted circular economy and sustainable development matters. In this paper - as was marked in abstract - the major attention will be focused on practical implementation of the postulates of improving the quality of life through the using of circular economy approach, which is an expression of sustainable development.

Nowadays, circular economy concept is one of the most popular issue, interested both practitioners, politician, and scientists. Defining, both the circular economy and circularity, is very difficult, due to the various approaches. Since crucial article of Kirchherr, Reike, and Hekkerts (2017), presented the literature review of 114 definitions of circular economy, newer papers often refer to the main conclusion of that article from 2017 (see i.e. Prieto-Sandoval et al. 2018; Camacho-Otero et al. 2018; Aguilar-Hernandez et al. 2018; Ruiz-Real et al. 2018; Velenturf et al. 2019). Based on that analysis, in present article circular economy is defined as the description of an economic system that is based on business models which replace the 'end-of-life' concept with reducing, alternatively reusing, recycling and recovering materials in production/distribution and consumption processes (Kirchherr et al. 2017). These activities are done on three levels: micro, meso and macro and aiming at sustainable development in such a way that should lead to ensure the benefits for current and future generations. These three levels (micro, meso and macro) are understand as the levels of main actors of circularity process: both people, institutions and networks. What is worth to underline, all efforts taken by the actors in this process could have an impact on different dimensions (pillars) on which the concept of sustainability development is based. These pillars are: society, environment and economy (Diaz-Sarachaga et al. 2018). All the effects should be considered in these three dimensions. I assume that we cannot assess the process as positive while even if only in one dimension there will be a loss. Since the publication of Brundtland Report (1987) the present and future needs are presented as equally important. It means that taking each activity, aiming at meeting the present needs, we should take into consideration the possibility of meet the needs of future generations. The first association refers to the natural resources, but it is very difficult to predict how the technology will develop and which resources we will need in the future. It seems more reasonable to take quality 
approach in this analysis. The main question in this case is not: "which resources will we need?" but: "what level of quality of life we want to achieve?".

Before extending this thread, it is necessary to present sustainable development concept. Although, sustainable development as an expression, is rather well-known (on the Internet exist more than 408 million pages contain this expression in English), it needs to be underlined that this expression consists two crucial word: sustainable and development. The sustainability, etymologically derived from the word sustain, assumes that our common and future behaviour will be the same (or at the same level). This approach to understanding the sustainability concept underline the future right to use the common goods (or right for future generations to live as we would like to live). According to development, it is often identified wrongly as only quantity value (i.a. in economic analysis, when we try to present the set of indices that could testify that the analysed area is developed), while it is only the growing process. The growth is just a process effects multiplying production factors and consumer goods and has quantified character. The development is broader concept than growth due to the fact that it has a dynamic character and consists of two dimensions: quantitative changes (growth) and the qualitative changes in the economic and social area. However, the sustainable development is most often defined as a development that meets the needs of the present without compromising the ability of future generations to meet their own needs (Brundtland 1987), it does not exhaust the various ways of understanding this phenomenon. Deep analysis in this matter was conducted by Hopwood at al. (2005), in which Authors presented the results of mapping of views on sustainable development, showing the various approaches depended on increasing environmental concerns ( $1^{\text {st }}$ dimension) and increasing socio-economic wellbeing \& equality concerns ( $2^{\text {nd }}$ dimension). It is worth to underline that these two dimensions are also connected with the de-growth trend (but with using different approach). The de-growth trend is defined as an equitable downscaling of production and consumption that increases human well-being and enhances ecological conditions at the local and global level in the short and long-term (Kerschner 2010). However, this concept is not so new, but is postulated now by some circles with renewed force. It is an effect of taking climate- or environment-orientation in many aspects of present science and political discourse. Nevertheless, sustainable development taking into consideration environment as one of key dimension, it seems to be comprehensive point of view which ensures the wide range of potential activities. In this place, I would like to note that interactions between those three spheres: society, environment and economy could be different. Between society and environment, the interactions should be bearable, between environment and economy - viable, between economy and society - equitable, but between all those three - sustainable (Zikic 2018). The last one interaction is understanding as the optimal development which guarantees increasing the quality of life.

\section{The Approach to Measure of Quality of Life}

The quality of life is nowadays one of the most important aspect for modern society. This category is underline in many strategies, operational programs and different-level projects, but the common definition of this category is unavailable. In this paper, I assume that the quality of life is a multidimensional construct (Rapley 2003), which broadly encompasses how an individual measure the 'goodness' of multiple aspects (Theofilou 2013). Multidimensionality assumes both (a) possibility to take into consideration various plains of analysis, ex. types of capital (human, economic, etc.), utility of life dimensions (Petelewicz and Drabowicz 2016), and (b) various elements, ex. material aspects of life, main activity \& work, health, etc. (Statistics Poland 2017). Quality of life covers intangible, immeasurable issues (Piecuch and Chudy-Laskowska 2017) which means that to assess the quality of life the subjective measurement is applied. The concept closely related to quality of life is a living standard, but most authors distinguish between them (Babiarz et al. 2018; Bérenger and VerdierChouchane 2007; Błachut et al. 2017; Kasprzyk 2013; McGregor and Goldsmith 1998; Piasny 1993; Piecuch et al. 2018; Słaby 2007; Turkoglu 2015; Zeliaś 2000). Living standard concept is described by the living conditions and the level of meet the needs, which could be expressed by the set of objective indices. Ones of the most widely implemented measures in this subject are: 
a) Human Development Index (HDI), created by Mahbub ul Haq in 1990 with the help of Amartya Sen that measures the level of social development of countries (ul Haq 2003; Anand and Sen 1994);

b) Quality of Life Index that measures the quality of life in terms of i.a.: costs of living, health, safety and the environment (Kasprzyk 2013).

Both mention measures are in line with the postulate to "move away from GDP" put forward by The European Commission based on analysis of the most prominent scientists (Stiglitz et al. 2009; Fleurbaey and Blanchet 2013; Stiglitz et al. 2018).

Human Development Index is composed of indices which correspond to three basic dimensions of human development:

1. long and healthy life (indicator: life expectancy at birth),

2. knowledge (indicator: the mean/expected years of schooling),

3. material standard of living (indicator: an income index designed to proxy for purchasing power).

Despite of the potential of HDI, which is frequently used especially in international comparisons, many authors criticize it (Cahill 2005; Kovacevic 2010; Neumayer 2001; Noorbakhsh 1998, Pinar et al. 2015; Shaikh 2017) or - in a lighter version - propose its modification (Alkire and Foster 2010; Babiarz et al. 2018; Busato and Maccari 2016; Herrero et al. 2010; Maccari 2014; Migała-Warchoł 2017; Silva and Ferreira-Lopes 2014; Rahjou et al. 2014; Trabold-Nübler 1991) or modification of the mathematical model used to calculate it (Mishra and Nathan 2014). Nevertheless, using HDI (in assessment of the quality of life) seems to be the best way to ensure the possibility to compare the received results, especially when this index is compiled with another(s).

Quality of life index was developed by Carol Estwing Ferrans and Marjorie Powers in 1984 to measure quality of life in terms of satisfaction with life (Ferrans and Powers 1985). In formula proposed by Numbeo portal (calculated the value of Quality of Life Index every year for each country), the index is an estimation of overall quality of life by using an empirical formula which takes into account (Numbeo 2019):

1. purchasing power index,

2. pollution index,

3. house price to income ratio,

4. cost of living index,

5. safety index,

6. health care index,

7. traffic commute time index,

8. climate index.

Some of these indices are inhibitors, the rest of them are stimulants, what caused the necessity of transformation the inhibitors into stimulants (higher value of the index is better). The using of this index is not so wide as in HDI's case, but some research papers based on using it (Abilkayir 2019; Eusuf et al. 2018; Helwa and Saleh 2015; Ho 2015; Lapates et al. 2017; Polous 2018; Žmuk 2015). It seems to be comprehensive and takes into consideration various dimensions, but for the final opinion the critical analysis of the index is need (it is not a subject of this article).

Practical use of any concept (ex. indices) requires its operationalisation, which means firstly formulate the definition and secondly - use appropriate measures. As Mark Rapley (2003) said: It is routinely observed that not only do particular studies frequently lack a formal definition of QOL (quality of life - ed. author), but also that widely used measures of QOL fail to relate to an explicit theory of QOL and fail to show how QOL 'outputs' are related to 'inputs' in the shape of either public policy. To avoid this misunderstanding, in the case of quality of life, I use the definition mentioned above, and I exploit the data from both mention databases: Human Development Index: (http://hdr.undp.org/en/content/human-development-index-hdi) and Quality of Life: (https://www.numbeo.com/quality-of-life/rankings by country.jsp). 


\section{Implementation of the Circular Economy Approach}

Implementation of circular economy concept based on using various business models. It has practical dimension and it seems that theory of circular economy is later than practical solution operated in business. This statement need to be verify by conducting systematic literature review, however Heshmati (2015) prepared an analysis in this matter, and my own literature review results that the polish articles concerns circular economy were prepared for the first time after 2010, but this conclusion was drawn not on systematic analysis. Also, the crucial analysis prepared by Kircherr et al. (2017) and Korhonen et al. (2018b) indicated that the most part of articles concerns circular economy were written after the year of 2007, although Prieto-Sandoval et al. (2018) showed the earliest papers. Nevertheless, the literature about circular economy has become since 1990, when the circular economy was conceptualized by David Pearce and R. Kerry Turner (1990). Presented the economic system consists of production, consumption of goods, capital goods and resources as the input of the whole system. They noticed that: If we ignore the environment then the economy appears to be a linear system. Production $(P)$, is aimed at producing consumer goods $(C)$, and capital goods (K). In turn, capital goods produce consumption in the future. The purpose of consumption is to create 'utility' $(U)$, or welfare (Pearce and Turner 1990). Conducting the analysis, the Authors took into consideration: wastes, the Laws of Thermodynamics, entropy phenomenon and possibility of recycling. In conclusion They wrote: Instead of being an open, linear system, it is closed and circular and presented the circular model of economy (Pearce and Turner 1990).

Many of further papers are focused on practical implementation of circular economy approach, and presented many interesting practical examples come from business life (Alhola and Salmenperä 2019; Cavallo and Cencioni 2017; Davis et al. 2016; Diaz Lopez et al. 2019; Huerta Morales 2019; Kane et al. 2018; Lanz et al. 2019; Ellen MacArthur 2013), but also the scientists would like to fill the gap in theory (see: Galvão et al. 2018; Geisendorf and Pietrulla 2017; Kirchherr et al. 2017; Korhonen et al. 2018a; Korhonen et al. 2018b; Moreau et al. 2017; Prieto-Sandoval et al. 2018; Ritzén and Sandström 2017).

Implementation the circular economy approach into practice express by vide range of behaviour, starting from change the behaviours or habits in everyday life in the sphere of using the resources, through choosing proper materials or products and being aware of environmental consequences of our approach and ending on the implementation different business models into economy. 'Take-makewaste' approach, which is characteristic for the linear model of economy try to be replaced by 'reduce, reuse, recycle and recover' concept, which is used in circular economy. In case of linear economy, all resources are used only once. It means that their economic potential or broader - utility for consumers - are finished together with ending of using of the products. But resources using to manufacture the products are still in them. In effect, in our wastes there are many resources that can be used once again and this possibility depends on the technology we can use. In circular economy we use " $x \mathrm{R}$ " approach which means that depends on our activities the number of " $R$ " increases. " $R$ " means all taking efforts that have positive effect on environment (Table 1).

Table 1. Various "R" approach to circular economy implementation. (Kirchner et al. 2017; Manickam and Duraisamy 2019)

\begin{tabular}{llcl}
\hline Development & "R" Strategy & Detailed description & No. “R" \\
\hline $\begin{array}{c}\text { Smarter } \\
\text { product use } \\
\text { and } \\
\text { manufacture }\end{array}$ & R0 Refuse & $\begin{array}{c}\text { Make product redundant and abandoning its function } \\
\text { or by offering the same function with a radically } \\
\text { different product }\end{array}$ & $\begin{array}{c}\text { Make product use more intensive (e.g. by sharing } \\
\text { product) }\end{array}$ \\
\hline $\begin{array}{c}\text { Extend lifespan } \\
\text { of product and } \\
\text { its parts }\end{array}$ & R2 Reduce & $\begin{array}{c}\text { Increase efficiency in product manufacture or use by } \\
\text { consuming fewer natural resources and materials }\end{array}$ & $3 R / 4 R$ \\
\hline
\end{tabular}




\begin{tabular}{|c|c|c|c|}
\hline & R4 Repair & $\begin{array}{l}\text { Repair and maintenance of defective product so it can } \\
\text { be used with its original function }\end{array}$ & \\
\hline & R5 Refurbish & Restore an old product and bring it up to date & \\
\hline & R6 Remanufacture & $\begin{array}{l}\text { Use parts of discarded product in a new product with } \\
\text { the same function }\end{array}$ & \\
\hline & R7 Repurpose & $\begin{array}{l}\text { Use discarded product or its parts in a new product } \\
\text { with different function }\end{array}$ & \\
\hline \multirow{2}{*}{$\begin{array}{c}\text { Useful } \\
\text { application of } \\
\text { materials }\end{array}$} & R8 Recycle & $\begin{array}{l}\text { Process materials to obtain the same (high grade) or } \\
\text { lower (low grade) quality }\end{array}$ & $3 R / 4 R$ \\
\hline & R9 Recover & Incineration of material with energy recovery & $4 \mathrm{R}$ \\
\hline
\end{tabular}

Apart of the used strategy, thinking about implementation circular economy should be considered in depend on the stage of product development. It means, it is not enough to think about the product after its using, but before its creation. In effect, we received different concrete actions which could be apply in each phases: production, consumption and recovery (CircularPP 2019). Analyzed this issue from the point of view ensuring higher quality of life, the potential influence of each activity can be direct or indirect. It means that, chosen activities affect on increase of the quality of life in short or long time. Observed effects depend inter alia on the complexity of the business (production) system. Single effort taken by us, or complex actions taken by one person, are not effective. Only common, continuous effort for better future will be effective and will have a sense. Table 2 presents chosen circular actions that can be applied by single person (not an enterprise or industrial operators). The main criterion of choosing the action was direct impact on quality of life which is belonging to human. The description of some actions were changed, in purpose to present their connection with quality of personal life (not efficiency of enterprises as was in original material), as well as place of some actions (ex. 'sharing platform' is placed on consumption phase, not in production as in original).

Table 2. Different circular actions applied on different phase of the product lifecycle by the single user that have direct impact on quality of life.

\begin{tabular}{|c|c|c|}
\hline Stage & Action (strategy) & Description \\
\hline \multirow{3}{*}{ Production } & Circular design & $\begin{array}{l}\text { Including design for long life or life extension, for biological } \\
\text { cycle (separable biological and technical components, safe } \\
\text { materials, materials can return to nature), for resource } \\
\text { conservation. }\end{array}$ \\
\hline & $\begin{array}{l}\text { Long-life model or } \\
\text { performance model }\end{array}$ & $\begin{array}{l}\text { Products remain with their owners for a long time, through } \\
\text { maintenance, product attachment and upgrade or paying for } \\
\text { its use/access without formal ownership. }\end{array}$ \\
\hline & $\begin{array}{l}\text { Sufficiency model and } \\
\text { substitution }\end{array}$ & $\begin{array}{l}\text { Reducing absolute demand of resources by influencing and } \\
\text { mitigating consumerism behaviour and eliminating the need } \\
\text { of a product by a radical innovation or providing it in a } \\
\text { different way (e.g. de-materialization, shifting physical } \\
\text { products, services or processes to virtual ones). }\end{array}$ \\
\hline \multirow{3}{*}{ Consumption } & Sharing platform & $\begin{array}{l}\text { Facilitate a user-user interaction in the form of, physical or } \\
\text { virtual, platforms markets }\end{array}$ \\
\hline & Incentivised Revenue Model & $\begin{array}{l}\text { Use a revenue model that incentivises users (and all the } \\
\text { actors involved), to take actions to achieve circularity (ex. } \\
\text { selling, servicing the products, etc.). }\end{array}$ \\
\hline & $\begin{array}{c}\text { Circular criteria during } \\
\text { purchase }\end{array}$ & Use the circular criteria during purchase. \\
\hline Recovery & Reverse logistic & $\begin{array}{l}\text { A logistics plan aimed to take back (supplier's own) or collect } \\
\text { (other suppliers) products, components or materials. }\end{array}$ \\
\hline
\end{tabular}


Next-life sales and cascading

Retrofitting and material recycling
Selling a product (at the end of a "use-life") or transferring (to another supply chain or different end customer).

Renovating old infrastructures (ex. houses) and conducting downcycling, upcycling, or functional recycling.

Assessment direct impact of implementation circular economy on improving the quality of life requires conducting deep analysis with using detailed data (especially unit data come from questionnaire survey or focused interviews). For the purposes of this article, I conduct a preliminary analysis based on data available data from two mention international surveys (Human Development Index and Quality of Life Index).

\section{Methodology of Preliminary Analysis}

Due to the fact that the data concern the circular economy are limited (essential content, profile and time range), also the possibility to compare these data with the international quality of life databases is limited. In the present paper, which is the second one in the publication series treated about circular economy and its influence on our life, I decide to conduct and show preliminary analysis of dependence between circularity and quality of life. Data used within analysis come from two mention databases (HDI and QoL) as well as from Eurostat (circular economy indicator). The time range of availability of the data was the following:

- Quality of Life Index (2012-2019),

- Human Development Index (2010-2017),

- Circular material use rate expressed as \% of total material use (2010-2016).

Due to using Eurostat data, for analysis I chose only countries belongs to European Union. Unfortunately, for some of them Quality of Life Index was unavailable. Finally to the analysis, I choose 24 countries and limited the analysis between the indices to the common period of 2012-2016 (all indices were available for that time).

\section{Results}

The circular material use rate is expressed as \% of total material use. It is estimated that the global economy is only about 9\% circular (PACE 2019), European - 11\% (Eurostat 2020). We as society consume $50 \%$ faster than our resources are renewable, thus - if the consumption model remains at its current level - in 2030 we will need resources corresponding to two globes, while in 2050 it will be similar in size to three globes. Chart 1. Presents the mean of circular material use rate (CE) for analysed countries in available period of time (Box-Plots). Between 2010 and 2016 the highest values of this indicator were observed in the Netherlands, the lowest in: Croatia, Portugal, Ireland, Greece and Romania (depend on the year).

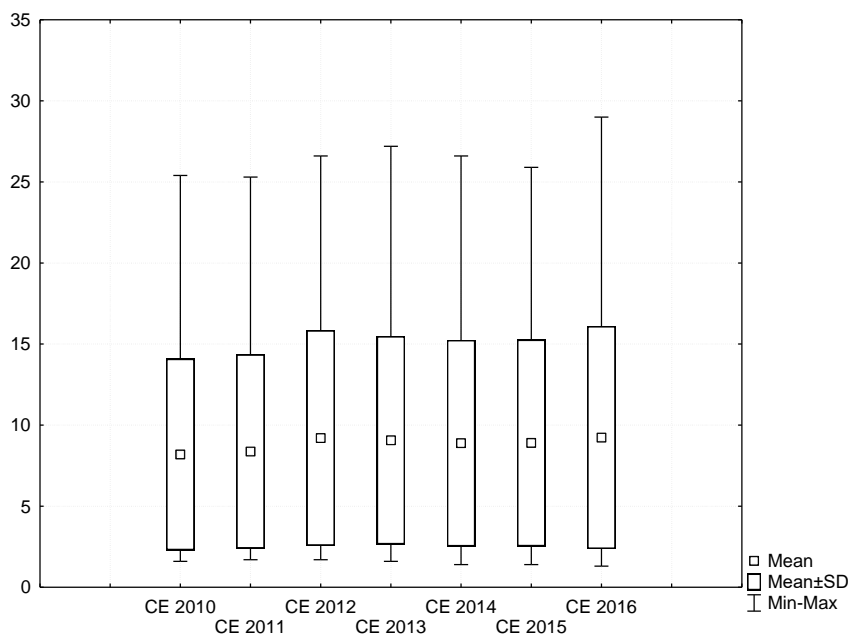


Figure 1. The mean of circular material use rate (CE) for EU countries in 2010-2016.

Source: (Eurostat 2020)

Mean value of Quality of Life Index of increased between the period of 2012 and 2019 from 102.02 to 164.78 points. Chart 2 presents the mean value of that Index for analysed EU countries. What is worth to underline, the difference between the countries were decreased (decreasing of minimum and maximum range, as well as value of standard deviation).

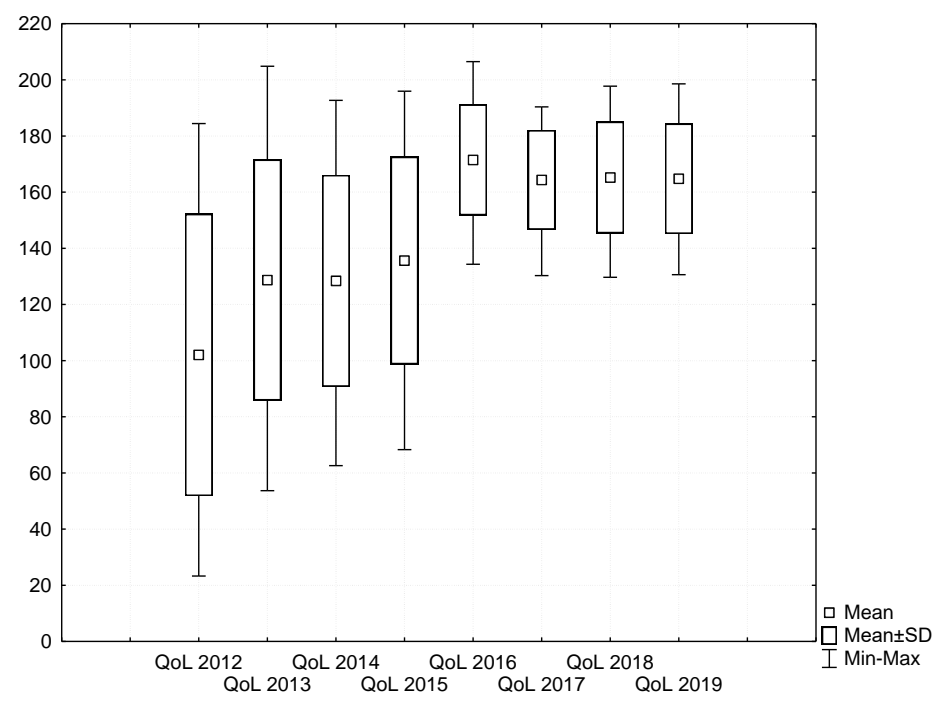

Figure 2. The mean of Quality of Life Index for EU countries in 2012-2019. Source: (Numbeo 2019)

Between 2012 and 2019 the highest values of this indicator were observed in German, Denmark and Austria, and the lowest in: Bulgaria, Greece and Lithuania (depend on the year).

Mean value of the last indicator used in present analysis - Human Development Index - increased between period of 2010 to 2017 from 0.864 to 0.889 . Chart 3. presents the mean value of that Index for analysed EU countries. The lowest values of the HDI in each year were observed in Bulgaria and Romania. The highest values were observed in Denmark, Ireland and Germany (depend on the year).

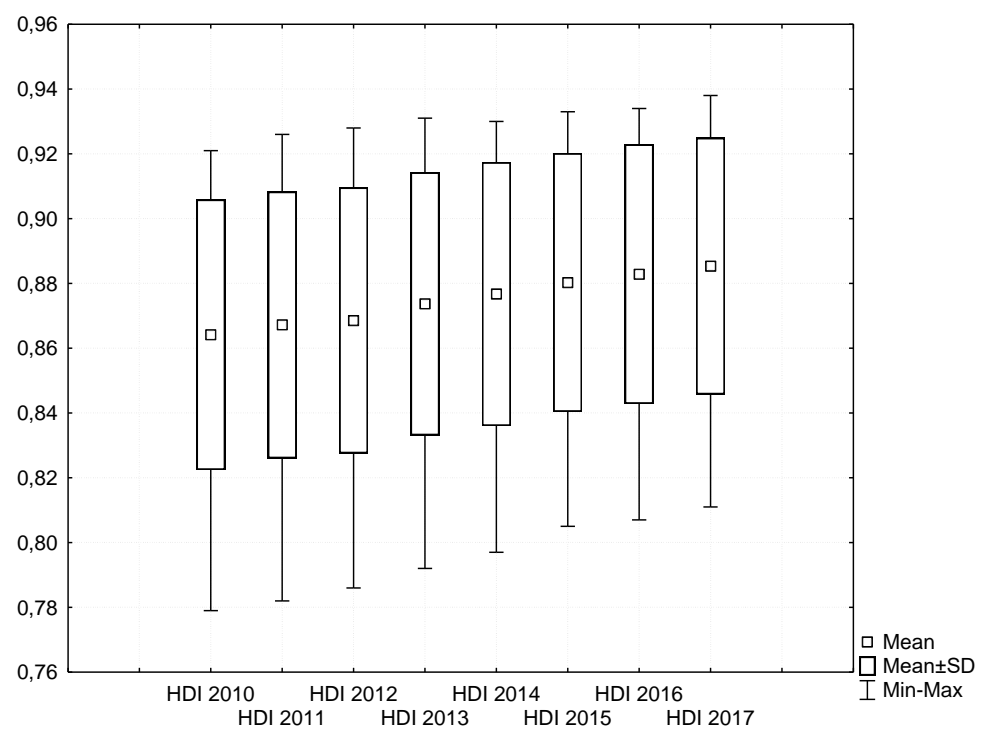

Figure 3. The mean of Human Development Index for EU countries in 2010-2017.

Source: (UNDP 2017)

In order to analyse the connection between circularity and increased quality of life, I standardized the values of each indicator and use Pearson's correlation coefficient and linear regression (Table 3). The statistically significant relation is observed only between HDI and CE; the relation between QoL 
and $C E$ is not statistically significant, what caused that in the analysis of linear regression only the dependence between CE (independent variable) and HDI (dependent variable) was estimated.

Table 3. The summary of results of linear regression between circularity (CE) and quality of life (HDI).

\begin{tabular}{|c|c|c|c|c|c|c|}
\hline Year & Multiple R & Multiple $\mathbf{R}^{2}$ & Adjusted $\mathbf{R}^{2}$ & $F(1,22)$ & $\begin{array}{c}p \\
(p<0.05)\end{array}$ & $\begin{array}{c}\text { Std.err. of } \\
\text { estimate }\end{array}$ \\
\hline 2012 & 0.561 & 0.315 & 0.284 & 10.111 & 0.004 & 0.846 \\
\hline 2013 & 0.559 & 0.313 & 0.281 & 10.007 & 0.0045 & 0.848 \\
\hline 2014 & 0.511 & 0.261 & 0.227 & 7.771 & 0.011 & 0.879 \\
\hline 2015 & 0.510 & 0.261 & 0.227 & 7.751 & 0.011 & 0.879 \\
\hline 2016 & 0.477 & 0.228 & 0.193 & 6.4961 & 0.018 & 0.898 \\
\hline Year & Component & Beta & $\begin{array}{c}\text { Std.err. of } \\
\text { Beta }\end{array}$ & B & Std.err.of B & $t(22)$ \\
\hline \multirow{2}{*}{2012} & Intercept & & & 0.000 & 0.173 & 0.000 \\
\hline & CE 2012 & 0.561 & 0.176 & 0.561 & 0.176 & 3.180 \\
\hline \multirow{2}{*}{2013} & Intercept & & & 0.000 & 0.173 & 0.000 \\
\hline & CE 2013 & 0.559 & 0.177 & 0.559 & 0.177 & 3.163 \\
\hline \multirow{2}{*}{2014} & Intercept & & & 0.000 & 0.179 & 0.000 \\
\hline & CE 2014 & 0.511 & 0.183 & 0.511 & 0.183 & 2.788 \\
\hline \multirow{2}{*}{2015} & Intercept & & & 0.000 & 0.179 & 0.000 \\
\hline & CE 2015 & 0.510 & 0.183 & 0.510 & 0.183 & 2.784 \\
\hline \multirow{2}{*}{2016} & Intercept & & & 0.000 & 0.183 & 0.000 \\
\hline & CE 2016 & 0.477 & 0.187 & 0.477 & 0.187 & 2.549 \\
\hline
\end{tabular}

The regressions' models are consisting on independent variable only in each year (without intercepts). The results are statistically significant, but not explain the whole dependency. Adjusted $\mathrm{R}^{2}$ reaches the values between 0.193 and 0.284 , what means that in maximum only $28 \%$ of the model is explained by this combination of variables. To verify the correctness of the models built in this way, analysis of variance was used (tested hypothesis assumes that there is no difference between means: $H_{0}: \alpha_{1}=0$ ). The results of the analysis allow to reject of the tested hypothesis. The F-ratio (from Sndecor's F-distribution) for degrees of freedom (1\&22) counts 6.4961 and in each year F is higher than tested ratio (in 2016 is equal, but the difference appears in 6 place after decimal, so I have decided to approve this observation). It can therefore be said that each of the models is correctly matched to the data.

\section{Discussion}

The results of literature review allow to state that there is a lack of analysis of influence of circularity on increasing quality of life. It is possible to assume that the influence exists and it is positive, but there is no evidence based on detailed data. The attempt to evaluate of the connection between increasing circularity (express by use circular materials) and increasing the quality of life level, based on international, aggregated data shows positive impact but in some conditions. Firstly, using indicators concerns the same matter could affects different results (HDI is correlated, and QoL not). It is caused probably due to the construction of the indices and lack of changing methodology of its counting (QoL was changed slightly in analysed period). Secondly, overall data do not reflect the whole spectrum of analysed phenomenon. Adjusted determination coefficient (Adjusted $R^{2}$ ) in my opinion is not so satisfied and testifies that it is necessary to enrich the model of influence the quality of life by new variables (but it could not reflect only the circular aspects). On that base I can state that there is a real need to conduct deep analysis of several aspects related with circular behaviour of single household members on the chosen quality of life dimension. It is caused the fact, that quality of life has various dimension and is very broad concept, so circularity and - in result - circular economy has 
not got direct influence of all of them. So, that is why, there is a need to narrow down the analysis to only direct factors.

Due to the fact, that the present paper is one from the publication series, in next I try to undertake this issue once again and deepen the analysis.

\section{References}

Abilkayir Nazerke A. 2019. Population health as a major factor of quality of life. News of the National Academy of Sciences of the Republic of Kazakhstan: 2(332), 20-27. https://doi.org/10.32014/2019.2519-1629.16.

Aguilar-Hernandez Glenn A., Sigüenza-Sanchez Carlos Pablo, Donati Franco, Rodrigues João F. D., and Tukker Arnold. 2018. Assessing circularity interventions: a review of EEIOA-based studies. Economic Structures: 7, 14. https://doi.org/10.1186/s40008-018-0113-3.

Alhola Katriina, and Salmenperä Hanna. 2019. Summary report work package 2.1 State-of-the-art on Circular Procurement Policy in the Baltic Sea region. Helsinki: Finnish Environment Institute (SYKE). Available online: http://circularpp.eu/wp-content/uploads/2019/06/Summary-Report-WP-2.1-State-of-the-art-of-CircularProcurement-Policy.pdf (accessed on 3 January 2020).

Alkire Sabina, and Foster James. 2010. Designing the Inequality-Adjusted Human Development Index (IHDI). Human Development Research Paper 28/2010 [Report]. New York: Human Development Report Office.

Anand Sudhir, and Sen Amartya K. (eds.). 1994. Human Development Index: Methodology and Measurement. Human Development Report Office Occasional Papers vol. 12. New York: Human Development Report Office.

Babiarz Patryk, Grabiński Tadeusz, Migała-Warchoł Aldona, and Szczygieł Elżbieta. 2018. The application of customized human development index to the analysis of socio-economic development of the European Union member states. Economics and Sociology: 11(4), 332-342. https://doi.org/10.14254/2071-789X.2018/11$4 / 22$.

Bérenger Valérie, and Verdier-Chouchane Audrey. 2007. Multidimensional Measures of Well-Being: Standard of Living and Quality of Life Across Countries. World Development: 35(7), 1259-1276. https://doi.org/10.1016/j.worlddev.2006.10.011.

Błachut Barbara, Cierpiał-Wolan Marek, Czudec Adam, and Ślusarz Grzegorz. 2017. Jakość życia w województwie podkarpackim w latach 2004-2015 ['Quality of life in the Podkarpackie Voivodeship in 2004-2015']. Rzeszów: Urząd statystyczny w Rzeszowie.

Brundtland Gro Harlem. 1987. Our Common Future. Report of the World Commission on Environment and Development, United Nations. Available online: https://sustainabledevelopment.un.org/content/ documents/5987our-common-future.pdf (accessed on 3 January 2020).

Busato Francesco, and Maccari Norma. 2016. The Environmental Human Development Index. Rivista di Studi Sulla Sostenibilita': 14, 31-44. https://doi.org/10.3280/RISS2016-002004.

Cahill Miles B. 2005. Is the Human Development Index redundant? Eastern Economic Journal: 31(1), 1-5.

Camacho-Otero Juana, Boks Casper, and Nilstad Pettersen Ida. 2018. Consumption in the Circular Economy: A Literature Review. Sustainability: 10, 2758-2784. https://doi.org/10.3390/su10082758.

Cavallo Marino, and Daniele Cencioni. 2017. Circular economy, benefits and good practices. Milano: Edizioni Ambiente.

CircularPP. 2019. Infographic entitled: Circularity strategies enterprises apply different strategies in relation to design, production and recovery. Available online: http://circularpp.eu/wp-content/uploads/2019/07/circ2.jpg (accessed on 3 January 2020).

Davis Michael Maks, Jácome Polit David, Lamour Mathieu. 2016. Social Urban Metabolism Strategies (SUMS) for Cities. Procedia Environmental Sciences: 34, 309-327. https://doi.org/10.1016/j.proenv.2016.04.028.

Diaz Lopez Fernando J., Bastein Ton, and Tukker Arnold. 2019. Business Model Innovation for Resourceefficiency, Circularity and Cleaner Production: What 143 Cases Tell Us. Ecological Economics: 155, 20-35. https://doi.org/10.1016/j.ecolecon.2018.03.009.

Diaz-Sarachaga Jose Manuel, Jato-Espino Daniel, and Castro-Fresno Daniel. 2018. Is the Sustainable Development Goals (SDG) index an adequate framework to measure the progress of the 2030 Agenda? Sustainable Development: 26, 663-671. https://doi.org/10.1002/sd.1735.

Ellen MacArthur Foundation. 2013. Towards the circular economy. Vol. 1. Available online: https://www.ellenmacarthurfoundation.org/assets/downloads/publications/Ellen-MacArthur-FoundationTowards-the-Circular-Economy-vol.1.pdf (accessed on 3 January 2020). 
Eurostat. 2020. Database: Circular material use rate 2010-2016. Available online: https://ec.europa.eu/eurostat/databrowser/view/cei_srm030/default/table?lang=en (accessed on 3 January 2020).

Eusuf Muhammad Abu, Saadmann Muhammad, Mehbub Muhammad, and Ibrahim Mansor. 2018. A Review of the Parametric Characteristics of Urban Environment and it's Influence to the Urban Quality of Life. Environment-Behaviour Proceedings Journal: 3(7), 341-349. https://doi.org/10.21834/e-bpj.v3i7.1181.

Ferrans Carol E., and Powers Marjorie J. 1985. Quality of Life Index: Development and psychometric properties. Advances in Nursing Science: 8(1), 15-24. https://doi.org/10.1097/00012272-198510000-00005.

Fleurbaey Marc, and Blanchet Didier. 2013. Beyond GDP: Measuring Welfare and Assessing Sustainability. New YorkOxford: Oxford University Press.

Galvão Graziela Darla Araujo, de Nadae Jeniffer, Clemente Diego Honorato, Chien Guilherme, amd da Carvalho Maryl Monteiro. 2018. Circular Economy: Overview of Barriers. Procedia CIRP: 73, 79-85. https://doi.org/10.1016/j.procir.2018.04.011.

Geisendorf Sylvie, and Pietrulla Felicitas. 2017. The circular economy and circular economic concepts - a literature analysis and redefinition. Thunderbird International Business Review: 60, 771-782. https://doi.org/10.1002/tie.21924.

Helwa Olfat Abd Elghany Soliman, Saleh Mohamed Yasser Lotfy. 2015. Waste from an architectural perspective as a way towards quality of life. Engineering Research Journal: 146, AA1-AA17.

Herrero Carmen, Martínez Ricardo, and Villar Antonio. 2010. Improving the Measurement of Human Development. Human Development Research Paper 12/2010 [Report]. New York: Human Development Report Office.

Ho Joseph Kim-keung. 2015. A review of the notions of Quality of Life (QoL) and livability based on Ackovian systems thinking. American Research Thoughts: 1(11), 2513-2532. https://doi.org/10.6084/m9.figshare.1528199.

Hopewood Bill, Mellor Mary, and O’Brien Geoff. 2005. Sustainable Development: Mapping Different Approaches. Sustainable Development: 13, 38-52. https://doi.org/10.1002/sd.244.

Huerta Morales Alberto. 2019. Alternative business models available for circular procurement. Aalborg: University of Aalborg. Available online: http://circularpp.eu/wp-content/uploads/2019/11/WP2.2-report.pdf (accessed on 3 January 2020)

Kane G. M., Bakker Conny A., and Balkenende Ruud. 2018. Towards design strategies for circular medical products. Resources, Conservation \& Recycling: 135, 38-47. https://doi.org/10.1016/j.resconrec.2017.07.030.

Kasprzyk Beata. 2013. Wybrane aspekty oceny dobrobytu ekonomicznego i jakości życia (ujęcie regionalne Podkrpacie) ['Selected aspects of assessing economic well-being and quality of life (regional perspective Podkrpacie)']. Rzeszów: Wydawnictwo Uniwersytetu Rzeszowskiego.

Kerschner Christian. 2010. Economic de-growth vs. steady-state economy. Journal of Cleaner Production: 18, 544551. https://doi.org/10.1016/j.jclepro.2009.10.019.

Kirchherr Julian, Reike Denise, and Hekkerts Marko. 2017. Conceptualizing the circular economy: An analysis of 114 definitions. Resources, Conservation $\mathcal{E} \quad$ Recycling: 127, 221-232. https://doi.org/10.1016/j.resconrec.2017.09.005.

Korchonen Jouni, Honkasalo Antero, and Seppälä Jyri. 2018a. Circular Economy: The Concept and its Limitations. Ecological Economics: 143, 37-46. https://doi.org/10.1016/j.ecolecon.2017.06.041.

Korhonen Jouni, Nuur Cali, Feldmann Andreas, and Eshetu Birkie Seyoum. 2018b. Circular economy as an essentially contested concept. Journal of Cleaner Production: 175, 544-552. https://doi.org/10.1016/j.jclepro.2017.12.111.

Kovacevic Milorad. 2010. Review of HDI Critiques and Potential Improvements. Human Development Research Paper: 33/2010 [Report]. New York: Human Development Report Office.

Lapates Jovelin M., Aribe Jr. Sales G., Barroso Jennifer P., and Damasco Beulah Joy K. 2017. Health Quality and Cost of Living in Asian Cities. Journal of Educational and Human Resource Development: 5, 40-50.

Lanz Minna, Nylund Hasse, Lehtonen Timo, Juuti Tero, and Rattya Kaisu. 2019. Circular Economy in Integrated Product and Production Development Education. Procedia Manufacturing: 33, 470-476. https://doi.org/10.1016/j.promfg.2019.04.058.

Levallois Clément. 2010. Can de-growth be considered a policy option? A historical note on Nicholas GeorgescuRoegen and the Club of Rome. Ecological Economics: 69(11), 2271-2278. https://doi.org/10.1016/j.ecolecon.2010.06.020.

Maccari Norma. 2014. March. Environmental sustainability and Human Development: a greening of Human Development. Working Paper. Available online: https://doi.org/10.2139/ssrn.2426073 (accessed on 3 January 2020). 
Manickam Parthiban, and Duraisamy Gopalakrishnan. 2019. 4 - 3Rs and circular economy. Processing, Manufacturing, and Design. The Textile Institute Book Series: 77-93. https://doi.org/10.1016/B978-0-08-1026304.00004-2.

McGregor Sue L. T., and Goldsmith Elizabeth B. 1998. Expanding our understanding of quality of life, standard of living, and well-being. Journal of Family and Consumer Sciences: 90(2), 2-6.

Migała-Warchoł Aldona. 2017. Wykorzystanie metodologii wskaźnika HDI do badania poziomu życia mieszkańców krajów Unii Europejskiej ['The use of the modified HDI indicator to research the level of living in the European Union countries']. Humanities and Social Sciences: XXII, 24(3), 187-195. https:/doi.org/10.7862/rz.2017.hss.52.

Mishra Srijit, and Nathan Hippu Salk Kristle. 2014. Measuring HDI - The Old, the New and the Elegant: Implications for multidimensional development and social inclusiveness. Asia Research Centre Working Paper: 63. London: London School of Economics. Available online: http://www.lse.ac.uk/asiaResearchCentre/_files/

ARCWP63-MishraNathan.pdf (accessed on 3 January 2020).

Moreau Vincent, Sahakian Marlyne, van Griethuysen Pascal, and Vuille François. 2017. Coming Full Circle. Why Social and Institutional Dimensions Matter for the Circular Economy. Journal of Industrial Ecology: 21(3), 497506. https://doi.org/ 10.1111/jiec.12598.

Neumayer Eric. 2001. The human development index and sustainability - a constructive propos al. Ecological Economics: $39,101-114$.

Noorbakhsh Farhad. 1998. The Human Development Index: some technical issues and alternative indices. Journal of International Development: 10, 589-605. https://doi.org/10.1002/(SICI)1099-1328(199807/08)10:5<589:: AID-JID484>3.0.CO;2-S.

Numbeo. 2019. About Quality of Life Indices At This Website. Available online: https://www.numbeo.com/quality-of-life/indices_explained.jsp (accessed on 3 January 2020).

PACE. 2019. THE CIRCULARITY GAP REPORT Closing the Circularity Gap in a 9\% World 2019. The Platform for Accelerating the Circular Economy (PACE). Available online: https://circulareconomy.europa.eu/platform/sites/default/files/circularity_gap_report_2019.pdf (accessed on 3 January 2020).

Pearce David, and Turner R. Kerry. 1990. Economics of Natural Resources and the Environment. Baltimore: Johns Hopkins University Press.

Petelewicz Marta, and Drabowicz Tomasz. 2017. Jakość życia - globalnie i lokalnie. Pomiar i wizualizacja. ['Quality of life - globally and locally. Measurement and visualization'], Łódź: Katedra Socjologii Ogólnej, Wydział Ekonomiczno-Socjologiczny, Uniwersytet Łódzki.

Piasny Janusz. 1993. Poziom i jakość życia ludności oraz źródła i mierniki ich określania [‘Living standard and quality of life of the population as well as sources and measures for their determination']. Ruch Prawniczy, Ekonomiczny i Socjologiczny: LV(2), 73-92.

Piecuch Teresa, Chudy-Laskowska Katarzyna, and Szczygieł Elżbieta. 2018. The living standard of the inhabitants of the Carpathian Euroregion. In Production Management and Business Development. Leiden: CRC Press/Balkema, pp. 179-183.

Piecuch Teresa, and Chudy-Laskowska Katarzyna. 2017. Jakość życia przedsiębiorców ze szczególnym uwzględnieniem kobiet prowadzących działalność gospodarczą ['The quality of life of entrepreneurs with particular emphasis on women running a business']. Studia i Materiaty. Miscellanea Oeconomicae: 21(3), 343354.

Pinar Mehmet, Stengos Thanasis, and Yazgan M. Ege. 2015. Measuring Human Development in the MENA Region. Emerging Markets Finance and Trade: 51(6), 1179-1192. https://doi.org/10.1080/1540496X.2015.1080517.

Polous Olga. 2018. Global indexes as a component of a comprehensive assessment of the country`s human capital. In Сучасні проблеми економіки: матеріали VIII Міжнародної науковопрактичної конференції (м. Київ, 16 жовтня 2018р.) ['Modern Problems of Economics: Proceedings of the VIII International Scientific Conference (Kyiv, October 16, 2018)'], Kiev: National Aviation University, 176-178.

Prieto-Sandoval Vanessa, Jaca Carmen, and Ormazabal Marta. 2018. Towards a consensus on the circular economy. Journal of Cleaner Production: 179, 605-615. https://doi.org/10.1016/j.jclepro.2017.12.224.

Quality of Life. 2020. Database: Quality of Life Index. Available online: https://www.numbeo.com/quality-oflife/rankings_by_country.jsp (accessed on 3 January 2020).

Rahjou Somaye, Imani Mohammad Naghi, and Sharifi Asghar. 2014. The Review of Human Development Index to Determine the Contribution of Higher Education in the Education Index. Bulletin of Environment, Pharmacology and Life Sciences: 3(II), 244-252. 
Rapley Mark. 2003. Quality of Life Research: A Critical Introduction. London: SAGE Publications.

Ritzén Sofia, and Ölundh Sandström Gunilla. 2017. Barriers to the Circular Economy - integration of perspectives and domains. Procedia CIRP: 64, 7-12. https://doi.org/10.1016/j.procir.2017.03.005.

Ruiz-Real José Luis, Uribe-Toril Juan, De Pablo Valenciano Jaime, and Gázquez-Abad Juan Carlos. 2018. Worldwide research on circular economy and environment: A bibliometric analysis. International journal of environmental research and public health: 15(12), 2699-2713. https://doi.org/10.3390/ijerph15122699.

Shaikh Salman Ahmed. 2017. Developing an Index of Socio-Economic Development Consistent with Maqāṣid alSharī'ah, Journal of King Abdulaziz University, Islamic Economics: 30(1), 117-129. https://doi.org/10.4197/Islec. 30-1.11.

Silva Rita, and Ferreira-Lopes Alexandra. 2014. A Regional Development Index for Portugal. Social Indicators Research: 118(3), 1055-1085. https://doi.org/10.1007/s11205-013-0455-z.

Słaby Teresa. 2007. Poziom i jakość życia ['Living standard and quality of life'] In Statystyka społeczna ['Social statistics'] (ed. Panek Tomasz), Warsaw: Polskie Wydawnictwo Ekonomiczne.

Statistics Poland. 2017. Jakość życia w Polsce ['Quality of life in Poland'], Warsaw: Statistics Poland.

Stiglitz Joseph E., Sen Amartya, and Fitoussi Jean-Paul. (2009). Report by the commission on the measurement of economic performance and social progress. Available online: https:/ec.europa.eu/eurostat/documents/118025/ 118123/Fitoussi+Commission+report (accessed on 3 January 2020).

Stiglitz Joseph E., Fitoussi Jean-Paul, and Durand Martine. 2018. Beyond GDP: Measuring What Counts for Economic and Social Performance. Paris: OECD Publishing. https://doi.org/10.1787/9789264307292-en.

Trabold-Nübler Harald. 1991. The human development index - A new development indicator? Intereconomics: 26, 236-243. https://doi.org/10.1007/BF02928996.

Turkoglu Handan. 2015. Sustainable Development and Quality of Urban Life. Procedia - Social and Behavioral Sciences: 202, 10-14. https://doi.org/10.1016/j.sbspro.2015.08.203.

Theofilou Paraskevi. 2013. Quality of Life: Definition and Measurement. Europe's Journal of Psychology: 9(1), 150162. https://doi.org/10.5964/ejop.v9i1.337.

ul Haq Mahbub. 2003. The Birth of the Human Development Index. In Readings in Human Development. Oxford: Oxford University Press, pp. 127-137.

UNDP. 2017. Database: Human Development Index. Available online: http://hdr.undp.org/en/content/humandevelopment-index-hdi (accessed on 3 January 2020).

Velenturf Anne P. M., Archer Sophie A., Gomes Helena I., Christgen Beate, Lag-Brotons Alfonso J., and Purnell Phil. 2019. Circular economy and the matter of integrated resources. Science of The Total Environment, 689, 963-969. https://doi.org/10.1016/j.scitotenv.2019.06.449.

Zikic Srdjan. 2018. A modern concept of sustainable development. Progress in Economic Sciences: 5, 143-151. https://doi.org/10.14595/PES/05/009.

Zeliaś Aleksander (ed.). 2000. Taksonomiczna analiza przestrzennego zróżnicowania poziomu życia w Polsce w ujęciu dynamicznym ['Taxonomic analysis of spatial diversity of living standards in Poland in a dynamic approach']. Kraków: Wydawnictwo Akademii Ekonomicznej w Krakowie.

Žmuk Berislav. 2015. Quality of life indicators in selected European countries: Hierarchical cluster analysis approach. Croatian Review of Economic, Business and Social Statistics: 1(1-2), 4254https://doi/org/10.1515/crebss-2016-0004. 